\title{
Recommendations to medical associations' governing bodies in their relationship with industry
}

\author{
Antonio Soda, Carlos Campillo, Oscar Arrieta, Rubén Burgos, Miguel Ángel Celis, Manuel De la Llata, \\ Judith Domínguez, José Halabe, Sergio Islas, Luis Jasso, Alberto Lifshitz, Mucio Moreno, \\ Ricardo Plancarte, Alejandro Reyes, Guillermo J. Ruiz-Argüelles, Emma Verástegui and Julio Sotelo \\ Comité de Ética y Transparencia en la Relación Médico-Industria, Academia Nacional de Medicina, Ciudad de México, Mexico
}

\begin{abstract}
Continuing medical education activities are often financially supported by pharmaceutical and device companies. With the purpose to ensure ethics and accountability in the management of this assistance, the Committee of Ethics and Transparency in the Physician-Industry Relationship of the National Academy of Medicine of Mexico formulates recommendations to medical associations' leaders in this text.
\end{abstract}

KEY WORDS: Sponsoring of medical events. Pharmaceutical industry. Donations.

The governing bodies of medical groups (medical colleges, associations, academies, medical societies, etc.) are in charge of addressing with the industry (both pharmaceutical and innovative industries of medical devices and diagnostic systems, tourism industry, transportation, among others) the potential financing of continuing medical education and promotion of their products during academic meetings. This is a huge responsibility, because they do it in representation of the members of their organizations. That forces them to observe an unimpeachable attitude to avoid suspicions and misinterpretations, which arise when economic issues are addressed. They are not autonomous, they are obliged to those represented by them, with whom they acquire the commitment to inform about their activities, avoid conflicts of interest and not to put particular interests over those of the associates, which will contribute to the strengthening of a good image of the association they represent. An attitude that arouses suspicion can tarnish that image, especially in recent times that some sectors of society have expressed concern for possible undue agreements between medical professionals and the industry.
To fulfill their responsibility and avoid suspicions in their financial relationship with the Industry, medical associations' governing bodies, in addition to observing a behavior that does not deviate from the fundamental ethical principles of medical profession, must act with transparency and inform their associates about their actions.

In order to safeguard the image of the medical professional community and to help medical associations' governing bodies to demonstrate that in their financial relationship with the industry they act with transparency and that their actions have the support of their members, the Committee of Ethics and Transparency in the Physician-Industry Relationship (Cetremi - Comité de Ética y Transparencia en la Relación Médico-Industria) of the National Academy of Medicine issues the following recommendations:

1. To act taking care of the good image of the medical profession, avoiding conflicts of interest that jeopardize it. To remember that they do not act in a personal capacity, but they are their associates' interlocutors and must essentially comply with the academic precepts and statutes of their associations.
Correspondence:

Julio Sotelo

E-mail: jsotelo@unam.mx
Date of reception: 05-09-2018

Date of acceptance: 13-09-2018

DOI://dx.doi.org/10.24875/GMM.M18000202
Gac Med Mex. 2018;154:529-530

Contents available at PubMed www.gacetamedicademexico.com 
2. The relationship with the pharmaceutical industry should be voluntary. There is no obligation to participate in it and it is interrupted without consequences in case of not reaching agreements.

3. Academic programs should have autonomy and no promotional commercial manipulation bias; any participation should have the patient benefit as supreme value.

4. They should not induce their associates to prescribe or not any medication or supply and they should prevent the industry from doing it.

5. They must inform their associates in detail about affairs with and support of the industry, specifying the amount received and its destination.

6 . When the support received is for academic activities, it should be destined for that purpose and the way it was spent be disaggregated in detail to their associates.

7. When the support is for promotional activities (e.g., sale of spaces in sponsored exhibitions or symposia), medical associations' governing bodies must inform their members about the amount received and its destination.

8. Medical associations' governing bodies should inform their members the list of benefits the industry provides in the form of grants (transportation, event registration fees, food), either directly to assistants or to the management. In the first case, said management will request the industry to provide the list of grant recipients.

9. Medical associations' governing bodies must inform their members about any personal support (international congress fees, travel expenses, fees for academic participation) they receive from the industry.

10. Medical associations' governing bodies must have documents demonstrating they informed their members about any support received from the industry and will show them upon request by any medical institution with representative moral authority. 